\title{
COMMON MOTIFS IN RUSSIAN AND HUNGARIAN FAIRY-TALES
}

\author{
Imre Pacsai \\ Habilitated Doctor of Philological Sciences, Professor \\ Nyíregyháza High School \\ (Nyíregyháza, Hungary) \\ e-mail: drpacsai@gmail.com
}

\begin{abstract}
Comparing the fairy-tales I observed many similar traits which prove the N. S. Trobetzky’s (1927) theory from cultural contacts in the «Russian cultural zone».

The study presents the problems connected with the specific structures compared Russian and Hungarian fairy-tales. The renamed Czech researcher of ethnography J. Polívka (1932) established that the structural element which named by technologic termini «priskazka» and the beginner structure of Russian folk-tale have individual character and is no typic for the other folklore tradition.

The scientific investigation of Russian and Hungarian folklore discovered the common structural element of compared Russian and Hungarian fairy-tales and the areal character of these structures commenced with cultural and linguistics contacts of the examined region.
\end{abstract}

Key words: Russian and Hungarian fairy-tales, specific structures, «priskazka», beginner structure, cultural and linguistics contacts, common structural elements, similar traits, results of the comparison

\section{ОБЩИЕ МОТИВЫ РУССКИХ И ВЕНГЕРСКИХ ВОЛШЕБНЫХ СКАЗОК}

\author{
Имре Пачаи \\ Хабилитированный доктор филологических наук, профессор \\ Ньиредьхазская Высшая школа \\ (Ньиредьхаза, Венгрия) \\ e-mail: drpacsai@gmail.com
}

\begin{abstract}
Аннотация. В настояшей статье рассматриваются вопросы, связанные со структурой русских и венгерских волшебных сказок. Наша компаративная работа была мотивирована как теорией Н. С. Трубецкого о восточном характере русской народной культуры, так и сходными элементами русского и венгерского фольклора. По мнению Й. Поливки (1932) специфичские структурные элементы, присказка и заключительная единица являются типичными мотивами великорусской сказки, которые не так свойственны европейским сказочным традициям. В результате сопоставления структуры русской и венгерской волшебной сказки обнаружились общие структурные единицы, обладающие общими функциональными и стилистическими признаками. При изучении фольклора восточных народов выявились ареальные признаки как русских так и венгерских структурных единиц.
\end{abstract}

Ключевые слова: структура русских и венгерских волшебных сказок, сходные элементы структуры, присказка, заключительный элемент, компаративная работа, функциональные и стилистические признаки, ареальный характер.

ВВЕДЕНИЕ. При исследовании культурных контактов русского народа с восточными народами, упомянутых Н. С. Трубецким (1927), важным источником служил русский фольклор. В работе В. Н. Чичерова Русское народное творчество (1959) говорится о том, 
что типичным жанром русского фольклора является сказка. Выводы И. Н. Чичерова подтверждается мнением и В. Я. Проппа и Е. М. Мелетинского (1976), который назвал волшебные сказки термином «мифологические сказки». В результате сопоставительного исследования русских волшебных сказок с волшебными сказками упомянуого культурного региона, определенного Н. С. Трубецким, обнаружились немалочисленные параллели в сопоставленных произведениях народного творчества. В сопоставленных волшебных сказках параллельные мотивы касаются как морфологии (сюжета) сказки, так и быта, и верований народов, установивших друг с другом тесные, интенсивные и длительные культурные и языковые связи.

\section{РЕЗУЛЬТАТЫ И ДИСКУССИЯ}

\section{О сходных мотивах структуры волшебной сказки}

В настоящей статье рассматриваются общие структурные и речевые элементы, свидетельствующие о языковых контактах.

Общие речевые элементы, использованные как в великорусских, так и в уральских и алтайских волшебных сказках, проявляются в форме разных стилистических элементов данного жанра фольклора.

Вопросы, связанные с великорусской народной сказкой широко рассматриваются в работе «Slovanské pohádky» (1932) «Славянские сказки» Йиржи Поливки. Стилистические проблемы волшебной сказки многосторонне рассматриваются в главе «O stilistice východoslovanských pohádek» (О стилистике восточнославянских сказок):

„Formálním stilistickým charakterem se podobaji sobě velkoruské, beloruské i maloruské pohádky větší menši mérou, ale velmi se liši od pohádek jiných národi̊ slovanských i národi̊ jazykově nepřibuzných. Zde se mají prozkoumati práve s tohoto hlediska, aby se zřetelněji objevila jejich shoda, po př́padě odlišnost....

Největši pozornost upoutaly dosud úvodní a závěrečné formulky. Jsou totiž nejcharakterističtějši a mnochdy zachovány lépe než vnitřní forma.

Před začátkem pohádky bývá zcela zvláštní „pre-lúdium”(priskazka nebo prizkazka). Tato „předpohádka” je často vtipná a velmi drastická, nezř́ldka necudná až oplzá..."

(Polívka 1932, 124)

(«По формальным стилистическим характерным чертам русские, белорусские и украинские сказки в большей или меньшей степени похожи друг на друга, но очень отличаются от сказок других славянских народов и от народов неродственных в языковом отношении. Здесь они должны быть исследованы с этой точки зрения для того, чтобы ясно проявилось их сходство или же различие. Наибольшее внимание привлекли к себе до сих пор вводные и заключительные формулы. Они, действительно, являются наиболее характерными и во многих случаях сохранились лучше, чем внутренняя форма. Перед началом сказки выступает совершенно своеобразная «прелюдия» (присказка). Эта «предсказка» часто остроумна и весьма резка, нередко неприхотлива до неприличия.»)

По мнению Й. Поливки, типичные стилистические мотивы великорусской сказки не свойственны фольклору других европейских народов. Важным аргументом оригинальности, по его мнению, является специфическая структура русской сказки, в которой особое место занимают вводный и заключительный элементы. 
Ценность своеобразных структурных мотивов присказки и заключительного элемента состоится в том, что они образуют самостоятельную сказку, выдуманную сказителем. Содержание присказки и заключительного элементна не имеет непосредственной связи с сюжетом волшебной сказки. В них на передний план выдвигается личность и красноречие сказителя, возбудившего интерес у своей публики к исполняемой им волшебной сказке. В конце повествования он окончательно хочет завершить действие, прощаясь со слушателями и желая вывести их из мира сказки.

Интерес исследователей к данным специфическим стилистическим элементам русской сказки подтверждает работа Р. Якобсона (1982). Известный русский лингвист также интересовался вопросами русской народной сказки. При изучении основных свойств русских волшебных сказок он принимает выводы Й. Поливки (1932). Р. Якобсон также подчеркивает неповторимость русской народной сказки, мотивы которой не используются ни у западных, ни у южных славян, ни у романо-германских народов. В работе Р. Якобсона кроме сюжетных вопросов, связанных с историзмом народной сказки, особое внимание уделяется также и структурно-стилистическим проблемам типичного жанра русского фольклора.

Особенности присказки явно отражаются в сказке известного народного сказителя Филиппа Павловича Господарева (1865-1938) «Солдатские сыны (Иван и Роман)», которая зафиксированав сборнике, «Русские народные сказители» (1990), составленном Т. Г. Ивановой.

В этом произведении народного творчества проявляется и стилистическая функция присказки и заключительного элемента. При толковании значимости этой сказки Т. Г. Иванова делает следующее замечание:

«Солдатские сыны (Иван и Роман). Господарев, № 2. Ук.303. Широко распространенный в восточнославянской сказочной традиции сюжет. Это одна из самых любимых сказителем сказок. Он рассказывал ее с соблюдением всей сказочной обрядности.» (РНC, 457).

Последнее из суждений Т. Г. Ивановой объясняет, почему мы выбрали иллюстрацией для типичного использования изученных нами структурных элементов данную сказку. Разработанная форма присказки и заключительного элемента неразрывно связаны с понятием сказочной обрядности, упомянутой составителем сборника. Сказка начинается с присказки, обладающей основными типичными формулами:

«В некотором царстве, в некотором государстве, именно в том, в котором мьл живем, за номером пятым, в этом доме проклятом, за номером седымым, где мы сейчас сидим. Это не сказка, это присказка. Сказка будет после обеда, наевиись мягкого хлеба, похлебав кисльх щей, чтоб было брюхо толщей...» (РНС, 275).

В присказке, исполненной мастером слова Ф. П. Господаревым, обнаруживаются все основные свойства, которые, по мнению Й. Поливки, типичны для данного структурного элемента русской народной сказки. Мы подчеркиваем в ней полнокровность народного юмора и использование рифмующихся языковых единиц. Формула присказки «Это не сказка, а присказка» обнаруживается и в сказке «Иван -дурак» из сборника А. Н. Афанасьева: 
«Дали мне колпак, да почали толкать; дали мне кафтан, я иду домой, а синичка летат и говорит: «Скинь да положь!» Взял скинул, да положил. Это не сказка, а присказка, сказка впереди!» (Афанасьев III, 238.)

Повествование сказителя заканчивается в соответствии со структурными закономерностями русской сказки, ее заключительным элементом: «Роман берет отца $u$ мать и отправляется в свое царство, и начал ијарствовать в своем иарстве, поживать $u$ бедных людей не обиждать. И я проехал, там очень хорошо жсивется, как у нас сейчас. Ну, и сказка кончена» (РНС, 293).

В сказке «Вещий дуб» из сборника А. Н. Афанасьева, присказка служит прелюдией сюжета, о чем упоминается в работе Й. Поливки:

«Тошно молодой жене с старым мужем, тошно и старику с молодой женой! В одно ушко влезет, в другое вылезет, замаячит - в глазах одурачит, из воды суха выйдет: $u$ видишь и знаешь, да ни в чем ее не поймаешь!» (Афанасьев III, 261)

Данный вводный элемент не начинает в прямом смысле сюжет сказки, а служит поучением, обращает внимание читателя на сущность содержания сказки. Поучение предшествует конкретным событиям, рассказанным по ходу развертывания сюжета сказки. Данная вступительная единица используется в народной драматургии, осведомляя зрителей о сущности сюжета определеной пьесы.

При изучении текста русских волшебных сказок, зафиксированных в сборнике А. Н. Афанасьева, которые могли послужить примером для сказителей XX века, используются специфические структурные элементы, упомянутые Й. Поливкой. Сказка «Фома Беренников» является типичной по структурным свойствам произведением, в котором обнаруживаются присказка, главный корпус сюжета и заключительный элемент, основные структурные элементы русской народной сказки.

Данная сказка начинается с известных для читателей (слушателей) русских народных сказок фразеологических оборотов:

«В некотором царстве-государстве жнл-был мужик Фомка Беренников.» (РС, 330) «Морока»: «В некотором царстве, в некотором государстве жкил-был матрос.» (РС, 289)

«Удалой батрак»: «В некотором царстве, в некотором государстве жкил-был старик со старухой.» (Афанасьев III, 236)

При изучении структурные свойства венгерской волшебной сказки наблюдаются сходные морфологические элементы, присказка и заключительная часть. Венгерский этнограф Иштван Бано подчеркивает то, что венгерская сказка состоит из пяти элементов, в которой присказка и заключительная часть являются типичной структурной особенностью.

В венгерской волшебной сказке «Csihán királyúrfi» (Чихан-королевич) из сборника венгерских народных сказок, собранных выдающимся этнографом XIX в. Яношем Криза, наблюдается присказка, типичная для данного жанра венгерского фольклора:

"Egyszer volt, hol nem volt, hetedhét országon is túl, meg azon is túl, kidölt kemencének bedölt oldalában volt egy jegenyefa, annak a jegenyefának volt hatvanhat ága, s minden ágon hatvanhat varjú. Aki az én beszédemet meg nem hallgatja, a varjú üsse ki a szemét”. (Kríza 7)

(«Где было, там было, за семьдесят седьмым государством, из стены разваленной печи выросло одно высокое дерево. На этом дереве было 66 ветвей, на каждой из них сидела 66 ворон. Кто не склонит ухо на мои слова, пусть ему ворона выклюет глаза»). 
Вариант вышеупомянутого типа присказки, в которой тоже преобладают мотивы, определяющие сказочное пространство, использован в сказке.

«A halhatatlanságra vágyó királyfi» («Королевич, желающий бессмертия») из сборника Я. Криза. В данной структурной единице сказки кроме описания сказочного пространства обнаруживаются шутливые мотивы, использованные сказителем подобно вышеупомянутой присказке:

„Egyszer volt, hol nem volt, hetedhét országon is túl, még az Óperenciás tengeren is túl, bedölt kemencének kidölt oldalában, vénasszony szoknyájának hetvenhetedik ráncában volt egy fehér bolha, annak a kellös közepében volt egy fényes királyi város, a városban pedig lakott egy öreg király. Ennek a királynak volt egy jóravaló fia." (Kríza 99)

«Было не было, за 77-ым государством, за синими морями, на развалине печи, в 77-ой складке юбки старухи жила одна белая блоха. А в ее брюхе был один светлый королевский город, а в нем жил старый король. А у этого старого короля был замечательный сын.»

В призказке следующей венгерской волшебной сказки наблюдается цепочка шутливых картин, созидающие подходящие условия для повествования и веселое настроение слушателей сказки:

„Az égigérő fa” («Дерево до небес») : „Hol volt, hol nem volt, hetedhét országon is túl volt, fölnyergeltem egy fakót, fölültem a hátára, és kiszaladtam az erdöbe. Jól ittam, jól ettem, a fakót a fejemre tettem. Egyszer fölébredtem, ellopták a fakót. Akkor megijedtem. Fölszaladtam egy hegyre, hegyröl meg a fára. Úgy megráztam a fát, hogy az eper, szilva, mogyoró majd beszaggatta a fejem. Egyszer rám kiáltott egy öregasszony: - Haj, haj, te gyerek! Ne gázold el a répát, retket, mert nem te ültetted el a káposztát." (Illyés 1974, 57)

(«Где было, где не было, за семьдесят седьмой страной было. Я оседлал сивого коня, сел на него и выехал в лес. Хорошо напился, наелся и лег спать. Своего коня положил на голову как подушку. Пока я спал, коня украли. Очень испугался. Побежал на гору, на горе залез на дерево. Так стряснул дерево, что ягоды, сливы, орешки, сыпавшиеся с него, чуть не разбили мою голову. Вдруг старуха закричала, увидев меня: - Ты, негодяй, зачем ты топчешь редиску, морковку, да не ты посадил капусту»).

Своеобразный характер венгерской присказки наблюдается в сказке „Zsuzska és az ördög” («Жужка и черт») из сборника другого выдающегося фольклориста Ласло Араня. Главная функция присказки в данном фольклорном произведении - тоже описание места действия сказки, несмотря на упоминание о времени:

„Egyszer volt, hol nem volt, még az Óperenciás-tengeren is túl volt, volt a sós tenger kellös közepén egy lakatlan sziget, azon a lakatlan szigeten egy hagy hegy, annak a hegynek a tetején egy magas torony, annak a toronynak a leghegyibe egy könyv, abból szedtem én ezeket a szent beszédeket." (Arany 1979, 134)

(«Было не было, за морями-океанами, посреди соленого моря, на необитаемом острове стояла высокая гора, на ее вершине высокая башня, на самом верху которой была книга, из которой я и взял этот чудесный рассказ»).

Типичная заключительная формула русской волшебной сказки используется в конце сказки «Фома Беренников». Эта заключительная единица представляет относительно самостоятельную часть настоящего фольклорного произведения. Сказитель рассказывает свои приключения на пиру, устроенном на свадьбе главного героя: 
«И я там был, мед-вино пил, по усам текло, в рот не попало; ел я капусту, а в брюхе-то пусто. Дали мне колпак, стали со двора толкать; дали мне шльк, а я в подворотню шмыг! Дали мне синь кафтан; летят синицы да кричат: - Синь кафтан, синь кафтан! А мне посльшалось: «Скинь кафтан!». Скинул и бросил на дороге. Дали мне красныле сапоги; летят вороны да кричат: - Красные сапоги, красные сапоги! А мне послышалось: «Крадены сапоги!» Снял да и бросил. Дали мне лошадку восковую, плетку гороховую, уздечку репяную; увидал я - мужсик овин сушит, привязал тут лошадку - она растаяла, плетку куры склевали, а уздечку свиньи съели!». (Афанасьев III, 243)

Настоящая сказка соответсвует структурным нормам русской народной сказки, ведь в ней используются как обороты присказки, корпус сюжета, включающий в себя определенные мофологические элементы, так и заключительная часть сказки.

В самом конце сказки «Иван дурак» тоже используется заключительная формула: «Царь его угостил и отдал дочь; обвенчались они, и теперя жсивут, хлеб жуют. Я тут был, мед пил; по усам текло, в рот не попало. Дали мне колпак, да почали толкать; дали мне кафтан, я иду домой, а синичка летат и говорит: «Синь да хорош!» Я думал : "Скинь да положь!» «Взял скинул, да и положил». (Афанасьев III, 238)

По разработанности он является чуть ли не полным эквивалентом рассмотренной выше структурной единицы сказки «Фома Беренников», вошедшей в сборник А. Н. Афанасьева. При сравнении объема тождественных по функции структурных элементов обнаруживается различие лишь по богатству использованных оборотов. Многие обороты второй сказки передают тот же самый смысл, но более сжато, в более простой форме.

О типичности и богатстве формы свидетельствуют заключительные элементы русских народных сказок:

«Царевна-змея»: «Свадьба была богатая; на той свадьбе и я был, мед-вино пил, по усам текло, во рту не было.» (РС, 239)

«Сиротка-девочка»: «Я у ней была, мед пила, по губам текло, да в рот не попало. Вот и басне конец.» (PHC, 433)

Шутливые формулы обнаруживаются и в следующих сказках:

«Иван дурак» (РНС, 427-429): «Я у них была, чай пила, такие они славнье люди.» (PHC, 429)

«Данила» (РНС, 435-437): «Я у них была и чай пила, ну по губам текло, а в рот не попало Вся Вот так Данил женился на славу.» (РНС, 437)

«Буй-волк и Иван-царевич»: «Пир был задан на весь мир. Я там был мед-пиво пил и огурцами закусил.» (РНС, 390)

«Иван-царевич и Алихон-богатырь»: «Стал он жить да поживать и добра наживать.» (PHC, 405)

«Воробьюшек»: (РНС, 437-440). «Тут царь его жженил. Был там пир. Я была, танцовала да ногу сломала, и не поглядела этой свадьбы, не до того было, так меня водка с ног сбила.» (РНC, 440)

«По колена ноги в золоте, по локоть руки в серебре»: «B это время я там была, мед-вино пила, все видела, всем было очень весело, горько только одной старшей сестре.» (PC, 252)

По рассмотренным нами примерам складывается представление о вариантах основной сказочной формулы и также о ступенчатом характере полноты структуры-оригинала. 
Использование определенного оборота для сказителя является нормой. Изменяются лишь некоторые элементы данной структуры. Достойна внимания связь данной картины с мотивом свадьбы. Сказитель заканчивает сказку рассказом о своих приключениях, либо о событиях пира. Веселые картины свадьбы также имеют специфический ареальный характер, связанный с традициями и системой обрядов исследуемой культурной зоны.

Степень разработанности картины заключительного элемента наблюдается в вариантах этой структурной единицы. По нашему предположению, использование мотивов определяется не только одаренностью сказителя, но также и местными традициями повествования.

«Не любо - не слушай» : «Тут разложили они огонь, поставили горшок с крупами на таган и начали варить кашу. Когда каша сварится, тогда и сказка продлится, а теперь пока вся» (Афанасьев III, 219);

«Буй-волк»: «Такой был свадебный пир, продлжсалось целую неделю. Там вино рекой лилось, даже и выпить мне пришлось. Квасу и пива много пил, да только лишь усы замочил, а по усы текло в рот не попало» (РНС, 384);

«Доброе слово»: «На том пиру и я был,мед-вино пил, калачами заедал» (РС, 274).

«Иван Быкович»: «Я не пил, не ел, вздумал утираться, со мной стали драться; я надел колпак, стали в шею толкать!» (РС, 84).

В следующих сказках обнаруживаются другие формулы заключительного элемента, также использующие рифмующиеся языковые единицы: «Иванушка-дурачок»: «Был $y$ Иванушки колодец, в колодие рыба елец; а моей сказке конец.» (РС, 312)

«Дурак и береза»: «Люди смотрят - как есть козел, плюнули дураку в глаза и разошлись по домам. Сказке конец, а мне меду корец.» (РС, 314);

«Не любо - не слушай»: «Сказке конец, а мне меду корец». (Афанасьев III, 231);

«Лютонушка»: «Лутоня наелся донельзя, залез на полатки и уснул. Когда он проснется, тогда и сказка моя дале начнется, а теперь пока всея.» (РС, 317);

«Иванушка дурачок»: «Был у Иванушки колодец, в колодие рыба елец, а моей сказке конец.» (Афанасьев III, 197);

«Удалой батрак»: «Жили они богато; двор у них кольцом, три жердины конеи с кониом, три кола забито, три хворостины завито, небом покрыто, а светом обгорожено!» (Афанасьев III, 235).

В сказке «Вор» также наблюдается грубый крестьянский юмор, который типичен для многих русских пословиц и поговорок:

«Выпутался Сенька из беды, отрастил снова бороду и стал себе жсить-поживать, 8 чужое добро лапы запускать; и долго бы жил, да вот недавно повесили.» (Афанасьев III, 178)

\section{«Сказка о Василисе золотой косе, непокрытой красе и об Иване-горохе»:}

«Василиса жениха дождалась, а иүаревичу невеста нашлась. Четыре венца заказали, две свадьбы пировали, на веселье на радостях пир горой, мед рекой! Дедь дедов там были, мед пили, и до нас дошло, по усам текло, в рот не попало; только ведомо стало, что Иван по смерти отича принял изарский венеи, правил со славой державой, и в роды родов славилось имя ияаря Гороха.» (Афанасьев III, 326)

В русских народных сказках, исполненных А. К. Барышниковой, мы читаем следующую формулу: 
«Иван Водыч и Михаил Водыч»: «Вот когда они делилися и жсенилися, я там была, мед пила, по губкам текло, а в рот не попало. А живут хорошо, письма мне шлют, только они до меня не доходят» (РНС, 423).

Для венгерских волшебных сказок тоже свойственны заключительные сткуктурные единицы, которые тоже связаны с юморными событиями свадьбы главного героя. Сказитель является участником свадебного пира, где происходят юморные, но неприятные для него события.

Венгерская сказка „Szélike Királykisasszony” (Бенедек) «Ветерок-королевна» заканчивается шуточным заключительным элементом, типичным для фольклора изучаемой нами культурной зоны:

„Mingyárt nagy lakadalmat csaptak, üstre föztek, teknöre tálaltak. Csak lé volt kilencféle. Én is ott voltam ebédre. Ettem, ittam, jól mulattam, s aztán szépen elkullogtam." (Benedek 198)

«Тут же устроили свадебный пир. Столы ломились от явств. Только ухи было девять видов! Я на том пиру был. Ел-пил, хорошо повеселился, а потом удалился подобрупоздорову».

В венгерской сказке „Tejkút” («Молочный колодец») тоже используется картина свадьбы, где происходят шутливые события:

„Egyszeribe olyan lakodalmat csaptak, hogy telelö Szent Páltól tekerö Szent Pálig asztal asztalt ért. Én is ott voltam, kaptam egy kicsi csontikát, de odajött a keresztapám, s addig kérte, míg megharagudtam, s a lábához vágtam. Aki nem hiszi, nézze meg, még most is sántikál bele”. (Kríza 1972, 121)

(«После этого закатили такой пир, что свадебный стол простирался от одного села до другого. И я там был, получил одну косточку, но подошел ко мне крестный отец и так долго выпрашивал ее у меня, что я рассердился и бросил ее прямо ему в ногу. Если кто не верит, пусть посмотрит, он и сейчас хромает»).

В венгерской народной сказке «Ráadó és Anyicska» тоже обнаруживается шутливая заключительная формула сказки:

„Erre aztán még jobb kedvök kerekedett, még nagyobb lakadalmat csaptak, ettek-ittak, mulatoztak, Duna, Tisza, Dráva, Száva mind ott voltak egy szegletben, egy nagy zsákba beletömve, én is ott voltam, ugráltam, táncoltam, a zab sarkantyúmmal a zsákot kirúgtam, mind kidölt a sok víz; te is ott voltál majd a vízbe haltál, de én megkaptalak, üstöködnél fogva ki is rántottalak. Ha ki nem rántottalak volna, bizonyosan belehaltál volna." (Arany 1979, 65).

(«После этого им стало еще веселее. Еще больше закатили они свадебный пир». Ели-пили, веселились. Все большие реки сошлись туда, их собрали в один большой мешок, который стоял в углу. И я там был, плясал-танцевал, мои шпоры врезались в этот мешок, реки все вырвались из него. Произошел потоп. Ты тоже там был, чуть не утонул, я схватил тебя за волосы, вытащил из воды. Если бы тебя не вытащил, наверняка ты бы пропал»).

В венгерской этнографической работе «Népköltészet» (Венгерское народное творчество, 1988) в главе «A népmese mint népköltészeti müfaj» (Народная сказка как жанр фольклора, 19-36) также говорится о присказке и о заключительной формуле, как о типичном структурном мотиве венгерской народной сказки. Знаменитый венгерский фольклорист Иштван Бано (1982) предлагает дополнить трехэлементарную структуру волшебной сказки. По мнению И. Бано данные структурные элементы действительно 
являются самым первым, либо самым последним элементом сказки, но органически не связаны с сюжетом и могут сочетаться с разными сказками.

\section{Ареальные свойства присказки и заключительного элемента русской сказки}

Сказочная формула ж⿻ил-был является типичным элкментом русской народной сказки. Восточное присхождение этой формулы рассматривается в книге академика О. Б Ткаченко (1979). Украинский лингвист привел параллельные финно-угорские структуры:

«коми овны-вӧвны, удмуртскую улыны-вылыны, мордовскую эрямс-аштемс, состоящие из компонентов со значением «жить» и «быть, существовать». По его мнению, свидетельствуют о финно-угорском субстрате в русском языке.

Важной функцией присказки, начинающей русскую волшебную сказку «три царства - медное, серебряное и золотое» является обозначение и уточнение сказочного времени мифологической сказки.

«В то давнее время, когда мир божий наполнен был лешими, ведьмами да русалками, когда реки текли молочные, берега были кисельные, а по полям летали жареные куропатки, в то время жил-был иарь по имени Горох с изарищею Анастасьей Прекрасною; у них было три сына-циаревича.» (РС, 68)

Данный вопрос фольклора тщательно исследуется коми фольклористами О. И. Уляшевым и И. И. Уляшевым в работе «Онтология сказки» (1997). В главе этнографической работы «Время-пространство в реальном мире» авторы указывают на основную роль данного типа структуры, который служит ознакомлению слушателей с сакральными димензиями и введение их в этот чудесный мир.

В рассмотренной структурной единице русской сказки наблюдаются те же временные мотивы, которые обнаруживаются и в бурятских народных сказках. С вопросами бурятской народной сказки мы смогли познакомиться в работе Е. В. Баранниковой (1978), которая подчеркивает, что присказка в композиционном отношении является типичным мотивом также и бурятских волшебных сказок.

При рассмотрении специфических свойств структуры бурятской волшебной сказки Е. В. Баранникова анализирует композицию сказки «Аржа-Буржж $\boldsymbol{x a н » . ~ Ф у н к ц и я ~ б у р я т с к о и ̆ ~}$ присказки в основном соответсвует композиционному элементу, использованному в русской волшебной сказке. Функция данного типа присказки заключается в том, что она указывает на время действия, которое приурочивается к далекому прошлому:

«Когда вселенная преобразовалась, когда свиная голова стала съедобной, когда природа на земле установилась, когда гора Сумбер с бугорок была, когда в табуне рождались аргамаки, когда у отцов рождались баторы, когда земля была молодой $и$ красивой, когда время было благодатное, а бумага была тонкой, жил хан Аржа Буржа» (Бурятские народные сказки 1990, 225).

Установление сказочного времени обнаруживается и в присказке другого произведения бурятского народного творчества. Волшебная сказка «Сын Зээдэлэя, Газар Поолин» тоже начинается описанием времени чудесных событий:

«В те стародавние времена, когда погода стояла благодатная и травы ярко зеленели, когда земля была талая и свиньи отъедались, когда молочно-белое море лужицей виднелось, когда гора Сумбэр кочкой маленькой была, когда развесистое дерево опушки 
низкорослой порослью польхалось и круторогий козел маленьким козленком резвился, жил сын Зээдэлэя Газар Поолин со старухой» (Бурятские народные сказки, 426).

В присказках, использованных в венгерских волшебных сказках, в отличие от большее внимание уделяется описанию пространства, чем времени, связанного с сюжетом. Для обозначения времени служат сравнительно простые обороты также типа: «Egyszer volt, hol nem volt.» («Раз было - раз не было, был»); «Hol volt, hol nem volt, volt egyszer.» («Где было где не было, был»).

Обороты присказки венгерских волшебных сказок, имеют ареальный характер, типичны и для сказок тюркских народов. В татарском языке тоже известна сходная формула: «булмаса булган икен» (ТаРС, 83) «Была не была! Куда ни шло!» по толкованию узбекских фразеологов является обычным зачином узбекской сказки. Эквивалент данной формулы «бир бар экен, бир ёк экен» (ТуркмРС, 100) «раз было - раз не было» используется в туркменском фольклоре также элементом присказки. Параллельная формула использована в присказке турецких сказок: «bir varmiş bir yokmuş» (ТурРС, 894) «раз было - раз не было» (некогда, когда-то).

В более простых формах присказки в словацкой народной сказке используются также мотивы, возникшие под влиянием ареальных контактов:

Сказочное пространство нарисовано более разработанными картинами. Рассмотренный нами типичный зачин венгерской сказки использует формулы, свойственные узбекским и туркменским народным сказкам. Формула «бир бор экан, бир юк экан» (УзбРС, 73) «раз было - раз не было».

Заслуживает пристального внимания, что в русской народной речи структуры, соответствуюшие, формуле венгерской присказки «Egyszer volt, hol nem volt» (раз было - раз не было, был ) являются типичными языковыми средствами.

В пословицах, зафиксированных в сборнике В. Даля, используются структуры, в которых сочетаются однокоренные глаголы с утвердительным и отрицательным значением: «Живет не жсивет, а проживать проживает» (Д I, 82); «Был не был, жсил не жсил, знать, что пропал» (Д II, 71); «Едy, не еду, поехал» (Д II, 127); «Бойся не бойся, а року не миновать» (Д I, 40); «Была не была. Было не было - катай сплеча!» (Д I , 55); «Сорочи не сорочи, а без рубля быть» (Д I, 109); «Ушел, не ушел, а побежать можно» (Д I, 382);

О типичном использовании данной специфической структуры в русской народной речи свидетельствуют произведения русских народных писателей, в которых звучит язык народа:

«Была не была, сделаю, как она велела» (Бажов 189). «Делай не делай, а срок отбитый» (Бажов 277); «Покажет - не покажет, а засупа нашему брату будет». (Баж 328); «Думай не думай - сто рублей не деньги». (Шукшин 28); «- Грусти не грусти - што толку?» (Шукшин 34); «—Хошь не хошь - четыре отдал!» (Залыгин 362); «А там досматривай не досматривай... у всех вода» (Распутин 37); «Это значит, возить не перевозить» (Распутин 121).

В китайском языке сочетание утвердительной формы сказуемого является типичной структурой: Xiànzài nŭde fùmŭ sh-bu-shì zài Rìběn? (ОКЯ, 94) «сейчас твои родители в Японии». В данном вопросе сруктура $\boldsymbol{s h}$-bu-shì «буквально: находятся- не находятся?» выражает неосведомленнось собеседника. В другом вопросе Niúnăi zài bēizi li, sh-bu-shì? (ОКЯ, 94) «молоко в стакане?» тоже используется данная структура (Есть, нет? В стакне?). 
Вопрос: Tā lái de zăo-bu-zăo? (ОКЯ 241) «он рано пришел?» использует антагонические

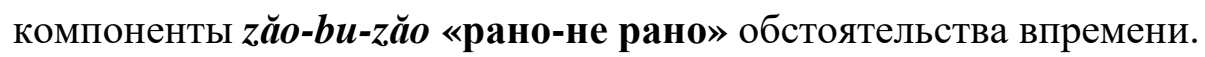

Следующие китайские примеры тоже используют структуру, соединяющую утвердительную и отрицательную формы сказуемого: Nĭde chĭzi cháng-bu-cháng? (ОКЯ, 34) «твоя линейка длинная? (длинная не длинная?)»; Nǐmende yuánzhūb̌̌ yíyàg-bu- yíyàg? (ОКЯ, 34) «у вас одинаковые шариковые ручки? (одинаковые не одинаковые?)». В этих примерах тоже используется частица, выражающая отрицательное значение именной части сказуемого. Стуктуры cháng-bu-cháng? «длинная не длинная» yíyàg-bu-yíyàg? «одинаковы не одинаковы?» представляют собой именную часть составного сказуемого.

Вопросы используют частицу méi дла передачи отрицательного значения в следующих примерах, в которых антонимическая структура уб̆и- méi- $\boldsymbol{y} \check{\boldsymbol{o u}}$ «есть- не есть»

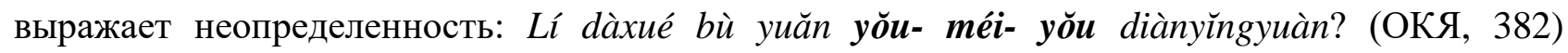
«недалеко от университета есть кинотеатр?»; Zài xиéyuàn fùyìn yø̆u-méi-yø̆u shítáng? (ОКЯ, 382) «вбизи института есть столовая?».

Представленные примеры подтверждают использование сходной специфической синтаксической структуры в разных языках изучаемого ареала, что говорит об общем приеме языковой модели.

Заключительный элемент русской сказки тоже обладает ареальным характером, о чем свидетельствуют следующие тюркские примеры.

Типичный оборот русской сказки, связанный с мотивом пира в заключительном элементе зафиксирован в сборнике русских пословиц: «По усам текло, да в рот не попало» (Д. I, 48). Данная общеизвестная формула, изученная и в работе Й. Поливки (1932), имеет эквиваленты в алтайской фразеологии.

Данная фразеологическая формула использована во многих русских сказках, как например: «О горе-горянине, Даниле - дворянине»: «Я там был, пиво пил; по усам текло в рот не попало; дали мне колпак - стали в шею толкать, дали мне ильк - я в подворотню и шмыз !» (Афанасьев, III., 375)

Сходство подтверждают как башкирская поговорка «кесе телгэ лэ йокманы» (БРС, 267) «до язычка не дошло (т. е. было мало еды)», так татарские примеры «Мыек чыланды, авызга кершеде» (ТаРС, 381); «по усам текло, в рот не попало»; «Лль телджсен утмэде, кече телге житмэн» (ТаРС, 409); «по большому языку не прошло, до маленького не дошло».

Достойно внимания тождество шутливой картины татарской сказки и русской пословицы из сборника В. И. Даля. «Пошел завтра, пришел сегодня» (Д I, 359), построенная из тождественных элементов. В основе шутливого мотива лежит инверсия порядка действий.

Заслуживает пристального внимания сходство между юморными картинами.

Об ареальном характере заключительной структуры русских народных сказок свидетельствуют и тюркские сказки. О типичном характере данной формулы свидетельствует татарская сказка «Гульчечек», использующая данный структурный элемент:

«Я у них был - вчера пошел, сегодня вернулся. Чаю с медом напился, пирогов наелся.» (Гульчечек 1952, 72) 
В известной татарской волшебной сказке «Камыр-батыр» (ТатНС, 15-20) «Тестобогатырь» шутливая формула заключения тоже связана с картиной свадьбы.

«Трицать дней пировали, сорок дней свадьбу справляли! И я на той свадьбе был, из пустого ковша мед пил». (ТатНС 20).

В другой татарской сказке «Тан-батыр» («Заря-богатырь») тоже используется данный мотив:

«Очень хорошо они живут. Сегодня я к ним ходил, вчера назад пришёл. С медом чай у них пил». (Тат. НС, 96).

Присказка в роли специфического элемента сказки обнаруживается и в чувашском фольклоре. Чувашским оборотам также свойственен рифм и народный юмор: В чувашской сказке «Батыр и Чиге Хурсахал» упрощенная форма заключительной формулы звучит так:

«И завели пир на весь мир. И я на том пиру был, обо всем этом узнал и сказку рассказал». (ЧНСК, 66)

Использование формул, независимых от сюжета наблюдается и в чувашских народных сказках: «юмӑх ярӑп, юптарӑn, йӑнӑш суулnа чуптарӑn» (ЧРС, 639) «я вам сказку расскажу, ложной тропкой поведу» (фольклор). В словаре подчеркивается, что данная формула является зачином чувашской сказки. Следующая формула служит присказкой в середине сказки: «шывее юхать лапалла, юмах пырать малалла» (ЧРС, 639) «бежит речка, извивается, сказка наша продолжается» (фольклор) Эта формула используется как концовка сказки: «юмах ятӑм, юптартӑм, пецр сӑмах та суймарӑм» (ЧРС, 639) «рассказал я сказку вам, нет ни слова фальши там».

Для соответствующего элемента венгерской народной сказки также свойственен полнокровный крестьянский юмор, проявляющийся в своеобразных картинах, в смешных ситуациях с целью развлечения слушателей.

Картина заключительного элемента венгерской волшебной сказки Tejkút («Молочный колодец») и туркменских волщебных сказок являются сходными:.

«После этого закатили такой пир, что свадебный стол простирался от одного села до другого. И я там был, получил одну косточку, но подошел ко мне крестный отец и так долго выпрашивал ее у меня, что я рассердился и бросил ее прямо ему в ногу. Если кто не верит, пусть посмотрит, он и сейчас хромает».

Сходная юморная картина обнаруживается в заключительной формуле в туркменской сказке «Караджа батыр» (Турк. НСК, 54-66):

«Я тоже побывал на этом пиру и ушел, завернув в полу кость. Но по дороге на меня бросился щзенок моего деда по матери. Я хотел швырнуть в него комком земли, да по ошибке кинул костью. Тут щенок и обглодал его». (Турк. НСК, 66)

В другой туркменской сказке «Два сына падишаха, рожденные от невольницы» (94-124) также использована заключительная формула, наполненная эмоциональной окраской:

«По этому случаю был устроен пир на несколько дней и ночей, резали баранов, варили плов. Я тоже нес с того пира миску плова и больщущую кость. Но вдруг на дороге споткнулся - плов по земле рассыпался. А кость пес Акбилек утащил. Так я голодным и остался.» (Турк. НСК, 124)

Заключительная формула используется сравнительно довольно часто в туркменских сказках, о чем свидетельствует сказка «Срота», в которой тоже использована данная 
стилистическая структура волшебной сказки исследуемого ареала. «A потом он устроил свадебный пир на сорок дней и ночей и взял пери в жены. На том пиру я был. И доставалась мне на том пиру большущая кость. Принес бы я ее Вам, да пес Алабай выхватил ее у меня из рук и убежал.» (Турк. НСК, 179)

Заключительный элемент венгерской сказки связана с описанием юморными событиями свадебного пира, где сказитель сказки тоже принял участие. Этот мотив тоже используются в туркменских сказках. Интересным общим элементом веселых картин является кость, которую сказитель получил от хозяев. Обглоданная кость говорит о том, как угостили и потчевали его. Этот скромный подарок теряется в следствии, неожиданных событий, что отражает «рустичный» народный юмор этих сказок.

ЗАКЛЮЧЕНИЕ. Результаты нашего иследования содействуют дополнению и модификации выводов Й. Поливки (1932) об уникальном характере структуры русской волшебной сказки, которые служили аксиомой для Р. Якобсона, изучающего вопросы русского фольклора. В основе неточности их выводов лежит тот факт, что для них венгерский фольклор был неизвестен, даже не имели точные знания о фольклоре алтайских народов Советского Союза.

Поливка подчеркивает то, что присказка и заключительная часть сказки являются независимыми частями волшебной сказки, и их использование во многом зависят от талантливости сказителя. Таким образом, мы можем установить, что сюжет волшебной сказки имеет коллективный характер, а независимые части имеют в большей мере индивидуальный характер. Культурный и языковой коллектив мог унаследовать сюжет сказки, который в основном сохранился, коренные мотивы не изменялись, несмотря на устный характер распространения сказки.

Й. Поливка и Р. Якобсон не явились собирателями волшебных сказок, они делали свои выводы по волшебным сказкам, зафиксированным в сборониках. В присказке и заключительной части волшебных сказок явно отражаются особенности речевой деятельности сказителя. Книга Русские народные сказители Т. Г. Ивановой чрезвычайно важна для исследователей, так как в этой работе представлена биография сказителя с данными о его жизни. В новых сборниках русских народных сказок сохранились все важные элементы стиля народного сказителя, даже особенности диалекта.

При сопоставлении русских и венгерских сказок обнаружились общие функциональные и стилистические признаки данного жанра фольклора. Использование этих структурных элементов служат деятельности сказителя, установить эмоциональный контакт со своей публикой и ввести слушателя в мир сказки, а потом вывести его из волшебного мира.

Для этих структурных единиц свойственен рустичный народный юмор, который не чужд ни культурным нормам сказителя ни нормам слушателей сказки. Этот мотив наблюдается у русских и венгерских народных сказок. Общим мотивом заключительного элемента является свадебный пир, участником которого является сам народный сказитель. Важным мотивом юмора является негативное событие, потеря скромных подарков, полученных на свадьбе, недостатки угощения. Эти мотивы наблюдаются как в русских, так и венгерских и сопоставленных тюркских сказках. 
Расширением круга компаративного исследования мы можем получить более точную информацию о стилистических и структурных свойствах данного жанра нардного творчества.

\section{LIST OF REFERENCES}

Barannikova, J. V. (1978). O burjatskoj volsebnoj skazke. Nauka. Moskva

Bikbulatov, N. V. (1974). Fol'klor narodov RSFSR. Ufa, s. 52-62.

Kaskabasov, S. A. (1972). Kazahskaja volšebnaja skazka Alma-Ata

Propp, V. Ya. (1969). Morfologija skazki. Moskva,

Propp, V. Ya. (1976). Fol'klor i dejstvitelnost'. Izbrannije statji. Moskva,

Stebleva, I. (1969). Turkmenskaja skazka In, Prodannij son Nauka. Moskva

Ulyashev, O. I., Ulyashev, I. I. (1997). Ontologija skazki Siktivkar.

Chicherov, V. I. (1959). Russkoje narodnoje tvorčestvo. Moskva. Izd. Mosk, Univ

Russkije narodnije skazš Москва. Изд. Моск. Унив,.

Banó, István Meseszerkezet és esztétikum. Ethn. XCIII. 233-258. ('Struktúra skazki i esztetika')

Berze Nagy, János (1957). Magyar népmesetípusok I-II. Pécs. ('Tipi vengerskich arodnich skazok')

Horálek K. (1962). Studie o slovanske lidové poezii. Praha.

Jakobson R. (1982). A költészet grammatikája. .Budapest. ('Grammatika poetiki')

Magyar néprajz V (1988). Népköltészet Akadémia Kiadó Bp. 1988. ('Vengerskij fol'klor. Narodnoje tvorestvo')

Pacsai, I. (2020). The role of Phraseology in the Russian popular writer's works // International ScientificPedagogical Organization of Philologists "WEST-EAST" (ISPOP). Scientific Journal WEST-EAST. Vol 3 N1 (October, 2020). pp. 19-28. https://doi.org/10.33739/2587-5434-2020-3-1928

Polívka, J. (1932). Slovanské pohádky (Vychodoslovanské pohádky) „Orbis” V Praze

Tkachenko, O. B. (1979). Sopostavitelno-istoricheskaya frazeologiya slavyanskih yazyikov i finno-ugorskih yazyikov. Kiev: «Naukova dumka».

Источники

Русский фольклор

Афанасьев Narodnije russkije skazki A. N. Afanasjeva v troch tomach Moskva, 1957

Д. І./II. Poslovici russkogo naroda. Sbonik V. Dal'a v dvuch tomach.HUd. lit. Moskva, 1984

PHC T. G. Ivanova: Russkije narodnije skaziteli. Izd. Pravda, Moskva,1989

РНСК Russkije narodnije skazki Русские народные сказки. Minsk 1977.

PC Russkije skazki. Hud. liter.Moskva. 1969.

Сборники венгерских народных сказок:

Arany László: Magyar népmesék. Budapest, Móra Ferenc Könyvkiadó, 1979.

Benedek Elek Világszép Nádszál Kisasszony és más mesék Bp.-Uzsgorod 1976.

Illyés Gyula Hetvenhét magyar népmese Bp. 1974.

Kríza János Csókalányok Budapest, Móra Ferenc Könyvkiadó, 1972

Алтайский фольклор

Baškirskoje narodnoje tvorčestvo. T. 3. Bogatirskije skazki Ufa, 1988

Baškirskij narodnij epos. Vost lierat. Moskva, 1977.

Burjatskije narodnije skazki Burjatskoje nar. izdateltvo Ulan-Ude 1973.

Burjatskije narodnije skazki. Hud. liter. Moskva. 1990.

KaHC Kazahskije narodnije skazki. Hud. liter. Alma-Ata, 1959.

Kigizskije narodnije skazki. Frunze, 1961.

Prodannij son. Turkmenskije narodnije skazki, Nauka. Moskva 1969.

ТатHC Gülčeček Tatarskije narodnije skazki Moskva, 1952.

50 
УзНC Uzbekskije narodnije skazki. Taškent.Gospolitizdat. 1955.

ЧHCK Čuvašskije narodnije skazki Moskva, 1961

Sokraščenije istočnikov

Бажов P. Bažov Malachitovaja škatulka Sovetskij pisatel', Moskva 1947.

БРС Baškirsko-russkij sovar Digora. Russkij jazik. Moskva, 1996.

Komissija

КирРС Kirgizsko-russkij sovar русский словарь. Moskva, 1965

КаРC Казахско- russkij sovar Moskva, 1981.

КРС Коми-пермяико-- russkij sovar. Moskva, 1985.

MaPC Marijsko-- russkij sovar. Joškar-Ola, 1991.

ОКЯ Osnovi kitajskogo jazika Moskva,

ONG O. Nagy Gábor: Magyar közmondások és szólások. Budapest, 1985.

ОШ Ošanin, I. M. Kitajsko-russkij slovar. Moskva, 1952.

Распутин $\quad$ Rasputin, V. Proščanie s Mat'oroj. Povesti. Minsk 1983.

TaPC Tatarsko--- russkij sovar. Moskva, 1966.

ТуркРC Turkmensko-russkij sovar. Moskva, «Sovetskaja enciklopedija ». 1968.

TyPC Turecko-russkij sovar. Russkij jazik Moskva, 1977.

УзбРС Uzbeksko-russkij sovar. Moskva, Russkij jazik 1959.

पPC Čuvašsko-russkij sovar. Moskva., 1977.

Шукшин Šukšin, V. Rasskazi. Hud. literatura.. Moskva 1983.

ЭРС Erzjansko- russkij sovar. Russkij jazik. Digora. Moskva, 1993.

\section{For citation:}

Pacsai, I. (2021). Common motifs in Russian and Hungarian fairy-tales // International ScientificPedagogical Organization of Philologists “WEST-EAST" (ISPOP). Scientific Journal WEST-EAST. Vol 5 N1 (March, 2021). pp. 37-51. https://doi.org/10.33739/2587-5434-2021-3-1-37-51

\section{Для цитирования:}

Пачаи, И. (2021). Общие мотивы русских и венгерских волшебных сказок // International ScientificPedagogical Organization of Philologists "WEST-EAST" (ISPOP). Scientific Journal WEST-EAST. Vol 5 N1 (March, 2021). C. 37-51.

https://doi.org/10.33739/2587-5434-2021-3-1-37-51

\section{Information about the author:}

Imre Pacsai - Habilitated Doctor of Philological Sciences Professor, Nyíregyháza High School, Member of the Scientific Council of the International Scientific and Pedagogical Organization of Philologists "WestEast" - ISPOP (Nyíregyháza, Hungary)

e-mail: drpacsai@gmail.com

\section{Сведения об авторе:}

Имре Пачаи - хабилитированный доктор филологических наук, профессор, Ньиредьхазская Высшая школа, член научного совета Международной научно-педагогической организации филологов «Запад-Восток» - ISPOP (Ньиредьхаза, Венгрия)

e-mail: drpacsai@gmail.com

Manuscript received: 11/01/2021

Accepted for publication: $11 / 02 / 2021$

Рукопись получена: 11/01/2021

Принята к печати: 11/02/2021 